\title{
MENINGKATKAN KEMAMPUAN KONEKSI MATEMATIK DAN SELF EFFICACY SISWA SMP MELALUI PENDEKATAN BRAIN BASED LEARNING
}

\author{
Ella Nurlatifah Ruyani Zain \\ SMP NEGERI 2 CIPANAS \\ Ellazain7@gmail.com
}

Penerimaan : 10 Juli 2018

Diterima: 30 Desember 2018

\begin{abstract}
ABSTRAK
Penelitian ini dilatar belakangi oleh fakta di lapangan yang menunjukkan bahwa kemampuan koneksi matematik san self efficacy siswa belum sesuai dengan harapan. Penelitian ini bertujuan untuk meningkatkan kemampuan koneksi matematik dan self-efficacy siswa menggunakan pendekatan Brain Based Learning. Metode peneitian ini adalah metode eksperimen dengan populasi seluruh siswa SMPN di Kabupaten Cianjur dan sampel dua kelas siswa SMPN 2 Cipanas yang dipilih secara acak kelas. Instrumen yang digunakan adalah instrumen tes dan non tes. Hasil penelitian menunjukkan peningkatan kemampuan koneksi matematik dan self-efficacy siswa yang menggunakan pendekatan Brain Based Learning lebih baik daripada yang menggunakan pembelajaran biasa. penelitian ini memiliki assosiasi untuk kedua variabel dengan kriteria sedang.
\end{abstract}

Kata Kunci : Brain Based Learning, Koneksi Matematik, Self-Efficacy.

\section{PENDAHULUAN}

Kemampuan koneksi matematik merupakan salah satu kemampuan berpikir tingkat tinggi yang sangat penting dan harus dikembangkan karena dalam pembelajaran matematika setiap konsep berkaitan satu sama lain dengan konsep lainnya. Lestari (2014) menyatakan bahwa anak perlu menyadari bagaimana hubungan antar konsep, karena antara sebuah bahasan dengan bahasan matematika lainnya saling berkaitan. Selanjutnya, Lestari (2014) mengungkapkan bahwa melalui koneksi matematik, wawasan siswa akan semakin terbuka terhadap matematika, yang kemudian akan menimbulkan sikap positif terhadap matematika itu sendiri. Melalui proses koneksi matematik, konsep pemikiran dan wawasan siswa terhadap matematika akan semakin lebih luas, tidak hanya terfokus pada topik yang sedang dipelajari.

Self-efficacy adalah keyakinan dari diri inividu pada kemampuannya untuk mengontrol kehidupannya atau perasaan untuk merasa mampu. Menurut teori Bandura (Yoenanto, 2010) self-efficacy membuat suatu perbedaan bagaimana individu : 1) merasa (feel), 2) berpikir (thimk) dan 3) bertindak (act). Self-efficacy juga membuat seseorang memilih situasi yang 
menantang, mengeksplorasi lingkungannya atau menciptakan lingkungan yang baru.

Faktanya, kemampuan koneksi dan Self-Efficacy matematik siswa masih rendah. Hal tersebut ditunjukkan dengan adanya kesulitan siswa saat mengerjakan soal soal koneksi matematik dan cenderung memiliki perilaku menyerah saat menemui kesulitan dalam mempelajari atau memecahkan masalah, Hal ini sesuai dengan pernyataan Bandura (Subaidi :2016) bahwa siswa yang memiliki Self-Efficacy rendah mengalami kesulitan dalam memecahkan tugas dan menganggap tugas tersebut sebagai ancaman terhadap dirinya. SelfEfficacy yang merupakan aspek afektif memberikan pengaruh untuk aspek kognitif atau saling terjadi asosiasi. Adanya asosiasi yang terjadi dapat meningkatkan kemampuan koneksi dan Self-Efficacy matematik siswa.

Salah satu upaya untuk meningkatkan kemampuan koneksi dan self efficacy matematik yang dilakukan penulis adalah mengggunakan metode pembelajaran yang menarik bagi siswa dan bisa membangun otak kira dan otak kanan secara seimbang, yaitu dengan menggunkan pendekatan Braind Based Learning dan dampaknya terhadap kemampuan koneksi serta SelfAfficacy siswa. Brain-Based Learning adalah suatu pembelajaran yang berdasarkan struktur dan cara kerja otak, sehingga kerja otak dapat optimal. Adapun fase pembelajaran BrainBased Learning menurut Jensen (Lestari:2014) yaitu: (1) pra-pemaparan; (2) persiapan; (3) inisiasi dan akuisisi; (4) elaborasi; (5) inkubasi dan memasukkan memori; (6) verifikasi dan pengecekan keyakinan; serta (7) perayaan dan integrasi.

Berdasarkan latar belakang masalah, permasalahan dalam penelitian ini dirumuskan sebagai berikut:

1. Apakah kemampuan koneksi matematik yang pembelajarannya menggunakan Brain Based Learning lebih baik daripada yang menggunkan pembelajaran biasa?

2. Apakah kemampuan self efficacy siswa yang pembelajarannya menggunkan brain Bsed Learning lebih baik daripada yang menggunkan pembelajaran biasa?

3. Apakah terdapat asosiasi antara kemampuan koneksi dengan Self-efficacy siswa?

\section{METODE PENELITIAN}

Metode penelitian yang digunakan dalam penelitian ini adalah metode eksperimen. Sedangkan Desain penelitian yang digunakan adalah desain kelompok kontrol pretes-postes (pretest-posttest-control group design). Desain penelitian menurut Ruseffendi (2010), sebagai berikut: 
$\begin{array}{llll}\mathbf{A} & \mathbf{O} & \mathbf{X} & \mathbf{O}\end{array}$

A 0 O

Keterangan:

A :Pengambilan sampel secara acak kelas

$\mathrm{O}$ :Instrumen Pretes $=$ instrumen postes pada kelompok eksperimen maupun kontrol

$\mathrm{X}$ :Perlakuan pembelajaran terhadap kelompok eksperimen dengan menggunakan metode Brain Based Learning

Penelitian ini dilaksanakan pada tanggal 19 Februari 2018 - 20 April 2018 . Populasi dalam penelitian ini adalah seluruh siswa SMPN di Kabupaten Cianjur, peneliti mengacak seluruh SMPN di kabupaten Cianjur sehingga terpilih SMPN 2 Cipanas. Setelah mengacak sekolah kemudian dilakukan acak kelas, pada pengacakan kelas di dapatlah kelas VII untuk digunakan sebagai sampel. Kemudian dilakukan pengacakan kembali untuk di ambil kelas eksperimen dan kelas kontrol dari kelas VII di SMPN 2 Cipanas, dari 11 kelas yang ada di kelas 7 atau dari kelas VII A sampai kelas VII K di dapat dua kelas yaitu kelas VII H sebagi kelas eksperimen dan kelas VII C sebagai kelas kontrol, untuk kelas eksperimen pemblajarannya menggunakan pendekatan Brain Based Learning dan satu kelas menjadi sedangkan kelas kontrol menggunakan pembelajaran biasa.

\section{HASIL DAN PEMBAHASAN}

Hasil uji hipotesis menunjukan bahwa kemampuan koneksi matematik dan self Efficacy siswa SMPN yang pembelajarannya menggunakan pendekatan Brain Based Learning lebih baik daripada kemampuan siswa yang menggunakan pembelajaran biasa. Seperti tampak pada Tabel 1. Rekapitulasi Hasil Tes Keampuan Koneksi Matematik dan Self Efficacy Siswa, menunjukkan bahwa rerata dan pencapian kelas eksperimen dengan menggunakan metode Brain Based Learning sebesar lebih tinggi dari rerata dan pencapian kelas kontrol.

Tabel 1. Rekapitulasi Hasil Tes Kemampuan Koneksi Matematik dan Self Efficacy Siswa Variabel Deskripsi Kelas dengan Treatment

\begin{tabular}{cccccccc} 
& & \multicolumn{3}{c}{ Brain Based Learning } & \multicolumn{3}{c}{ Konvensional } \\
\cline { 2 - 7 } & & Pretes & Postes & Gain & Pretes & Postes & Gain \\
\hline \multirow{2}{*}{$\begin{array}{c}\text { Kemampuan } \\
\text { koneksi }\end{array}$} & $\mathrm{N}$ & 32 & & & 32 & \\
\cline { 2 - 7 } & $\bar{x}$ & 12,15 & 18,69 & 0,41 & 10,85 & 13,57 & 0,18 \\
& $\%$ & $44 \%$ & $67 \%$ & $41 \%$ & $39 \%$ & $48 \%$ & $18 \%$ \\
\cline { 2 - 7 } & St. Dev & 3,10 & 2,85 & 0,16 & 2,87 & 2,43 & 0,97 \\
& Min & 3,00 & 13,00 & 0,06 & 6,00 & 7,00 & 0,06 \\
\hline
\end{tabular}




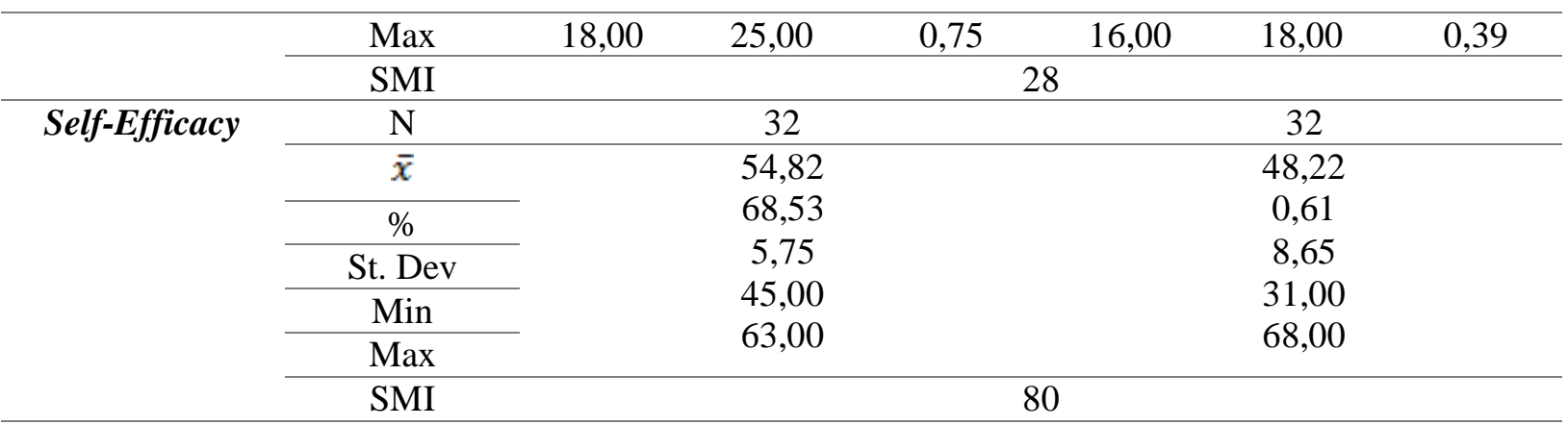

Berikut adalah hasil penghitungan perbedaan dua rerata (uji t) dan asosiasi antara kemampuan koneksi matematik dengan self efficacy siswa dengan menggunakan pendekatan Brain Based Learning.

Tabel 2. Uji Perbedaan Dua Rata-rata Data Postes Kemampuan Koneksi Matematik

\begin{tabular}{|c|c|c|c|c|c|c|c|c|c|c|}
\hline \multicolumn{11}{|c|}{ Independent Samples Test } \\
\hline & & \multicolumn{2}{|c|}{$\begin{array}{l}\text { Levene's } \\
\text { Test for } \\
\text { Equality of } \\
\text { Variances }\end{array}$} & \multicolumn{7}{|c|}{ t-test for Equality of Means } \\
\hline & & \multirow[t]{2}{*}{$\mathrm{F}$} & \multirow[t]{2}{*}{ Sig. } & \multirow[t]{2}{*}{$\bar{T}$} & \multirow[t]{2}{*}{ Df } & \multirow[t]{2}{*}{\begin{tabular}{|c|} 
Sig. \\
$(2-$ \\
tailed $)$
\end{tabular}} & \multirow[t]{2}{*}{$\begin{array}{c}\text { Mean } \\
\text { Difference }\end{array}$} & \multirow[t]{2}{*}{$\begin{array}{l}\text { Std. Error } \\
\text { Difference }\end{array}$} & \multicolumn{2}{|c|}{$\begin{array}{l}95 \% \text { Confidence } \\
\text { Interval of the } \\
\text { Difference }\end{array}$} \\
\hline & & & & & & & & & Lower & Upper \\
\hline postes_koneksi & $\begin{array}{l}\text { Equal } \\
\text { variances } \\
\text { assumed } \\
\text { Equal } \\
\text { variances } \\
\text { not } \\
\text { assumed }\end{array}$ & 659 &, 420 & $\begin{array}{l}7,759 \\
7,759\end{array}$ & 60,463 &, 000 & 5,12500 &, 66048 & $\begin{array}{l}3,80471 \\
3,80404\end{array}$ & 6,44596 \\
\hline
\end{tabular}

Dari tabel Independent Samples Test terlihat bahwa Sig. (2-tailed) equal variances assumed adalah sebesar 0,000 dan untuk Sig. (1-tailed) $=\frac{0,000}{2}=0,000$ lebih kecil dari 0,05 maka maka $\mathrm{H}_{0}$ ditolak dan $\mathrm{H}_{1}$ diterima dengan kata lain pencapaian kemampuan koneksi matematik siswa yang menggunakan pendekatan Braind Based Learning lebih baik daripada yang menggunakan pembelajaran biasa.

Tabel 3. Uji Perbedaan Dua Rata-rata Kemampuan Self-Efficacy

\begin{tabular}{|c|c|c|c|c|c|c|c|c|}
\hline & $\begin{array}{c}\text { Levene's } \\
\text { Test for } \\
\text { Equality of } \\
\text { Variances }\end{array}$ & \multicolumn{2}{|c|}{ t-test for Equality of Means } \\
\hline F & Sig. & T & Df & $\begin{array}{c}\text { Sig. } \\
(2- \\
\text { tailed })\end{array}$ & $\begin{array}{c}\text { Mean } \\
\text { Difference }\end{array}$ & $\begin{array}{c}\text { Std. Error } \\
\text { Difference }\end{array}$ & $\begin{array}{c}95 \% \text { Confidence } \\
\text { Interval of the } \\
\text { Difference }\end{array}$ \\
\hline
\end{tabular}




\begin{tabular}{|r|r|r|r|r|r|r|r|r|c|}
\hline & & & & & & & & Lower & Upper \\
\hline $\begin{array}{l}\text { Equal } \\
\text { variances } \\
\text { assumed } \\
\text { Equal } \\
\text { variances } \\
\text { not } \\
\text { assumed }\end{array}$ & 2,392 &, 127 & 3,588 & 62 &, 001 & 6,59375 & 1,83776 & 2,92012 & 10,26738 \\
self_efficacy & & 3,588 & 53,924 &, 001 & 6,59375 & 1,83776 & 2,90914 & 10,27836 \\
\hline
\end{tabular}

Dari tabel Independent Samples Test terlihat bahwa Sig. (2-tailed) equal variances assumed adalah sebesar 0,001 dan untuk Sig. (1-tailed) $=\frac{0,001}{2=}=0,0005$ lebih kecil dari 0,05 maka maka $\mathrm{H}_{0}$ di tolak dan $\mathrm{H}_{1}$ diterima dengan kata lain pencapiaan kemampuan self efficacy matematik siswa yang menggunakan pendekatan Braind Based Learning lebih baik daripada yang menggunakan pembelajaran biasa.

Analisis Asosiasi Antara Kemampuan Koneksi Matematik dengan Kemampuan SelfEfficacy siswa

Berikut ini disajikan hasil pengolahan data uji Chi-Square $\left(X^{2}\right)$.

Tabel 4. Deskripsi Statistik Asosiasi Kemampuan Koneksi Matematik dan Self-Efficacy Count

\begin{tabular}{|ll|r|r|r|r|}
\hline & & \multicolumn{3}{|c|}{ SELF_EFFICACY } & \multicolumn{2}{c|}{ Total } \\
\cline { 3 - 5 } & & TINGGI & \multicolumn{1}{|c|}{ SEDANG } & RENDAH & \\
\hline \multirow{2}{*}{ KEM_KONEKSI } & TINGGI & 1 & 4 & 8 & 13 \\
& SEDANG & 2 & 2 & 7 & 11 \\
Total & RENDAH & 2 & 2 & 4 & 8 \\
\hline
\end{tabular}

Selanjutnya dilakukan uji Chi-Square $\left(X^{2}\right)$ untuk kemampuan koneksi matematik dengan Self-Efficacy matematik

Tabel 5. Uji Chi-Square $\left(X^{2}\right)$ Kemampuan Koneksi Matematik dengan Self-Efficacy

\begin{tabular}{|l|r|r|}
\hline & \multicolumn{1}{|c|}{ Value } & \multicolumn{1}{c|}{ Approx. Sig. } \\
\hline $\begin{array}{l}\text { Nominal by Nominal } \\
\text { N of Valid Cases }\end{array}$ &, 508 &, 025 \\
\hline
\end{tabular}

Hasil Perhitungan data uji Chi-Square $\left(X^{2}\right)$ pada Tabel 5 terlihat bahwaAsymp. Sig. (2-sided) adalah 0,025 nilai tersebut memenuhi kriteriaAsymp. Sig. (2-sided) $\leq 0,05$ maka $H_{\circ}$ diterima yang artinya terdapat hubungan yang signifikan antara kemampuan koneksi matematik dengan Self-Efficacy siswa. Harga koefisien kontingensi $(C)$ dari Tabel 5 adalah 
sebesar 0,508. Selanjutnya dihitung nilai $Q$ sebagai berikut:

$$
Q=\frac{C}{C_{\text {maks }}}=\frac{0,508}{0,816}=0,63
$$

Berdasarkan kriteria derajat asosiasi pada Tabel 5 dapat disimpulkan bahwa terdapat asosiasi sedang antara kemampuan koneksi dengan Self-Efficacy matematik.

\section{Gambaran Kinerja Siswa}

Proses pembelajaran dengan pendekatan Brain Based Learning dilakukan pada kelas eksperimen. Sebelum memasuki pembelajaran peneliti membagi siswa mejadi beberapa kelompok. Satu kelompok masing-masing berjumlah anggota 4-6 orang sebagai tahap awal dalam pembelajaran, Tahap awal yang dilakukan pada pembelajaran ini di sebut tahap prapemaparan dimana pada tahap ini terdapat proses mengamati, pada proses ini guru memberikan tinjuaan pada pengetahuan siswa terkait materi bangun datar khususnya segiempat dan segitiga yang akan dipelajaridengan meminta siswa untuk mengamati peta konsep (mind map)yang disajikan oleh guru. Berikut adalah contoh mind maping yang disajikan:

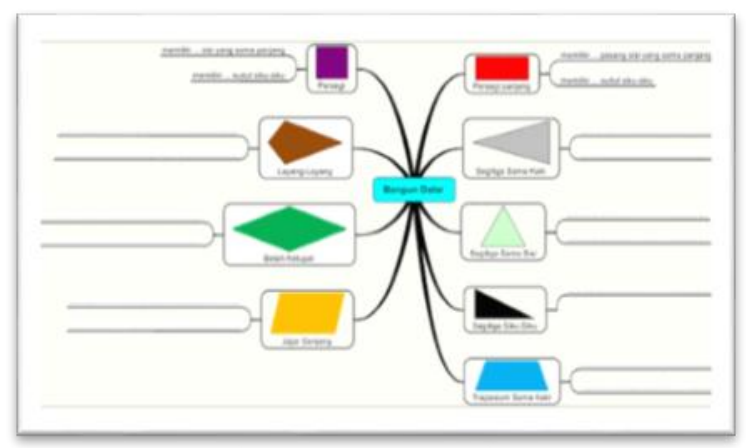

Gambar 1. Contoh Mind Mapping
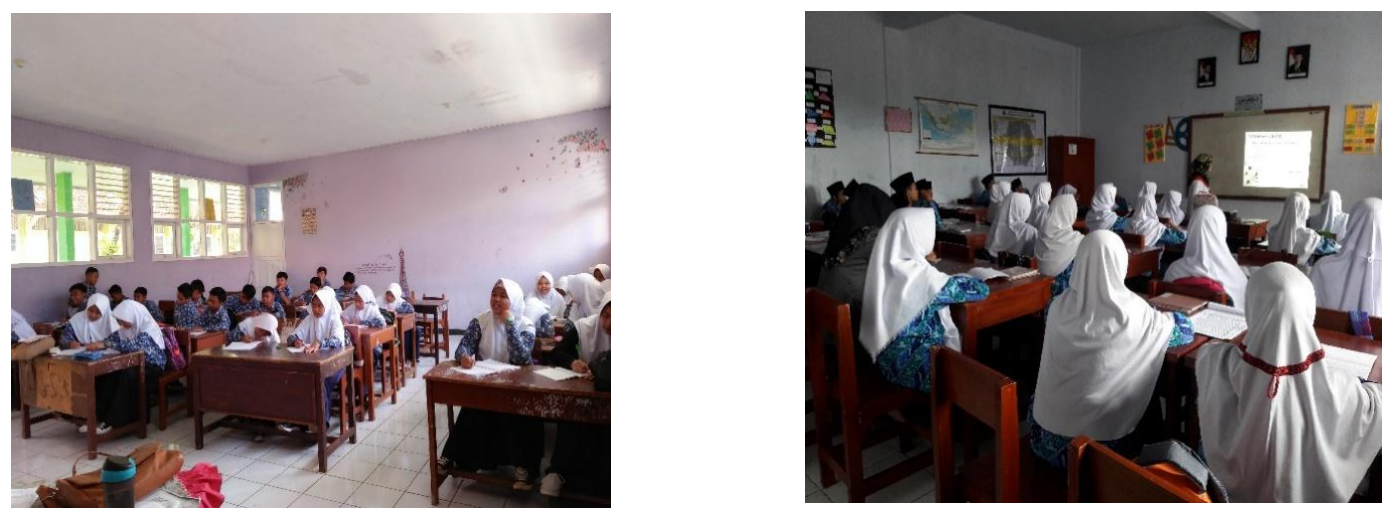

Gambar 2. Siswa Mengamati Mind Mapping yang Di Tampilkan Didepan 
Selanjutnya masuk ke tahap persiapan dimana guru merangsang keingintahuan dan kesenangan siswa akan pembelajaran matematika khususnya materi bangun datar menggunakan peta konsep yang harus dibuat oleh siswa yang kemudian gurupun menanyakan siapa siswa yang berani kedepan membuat dan menunjukan mind mapping yang mereka buat.
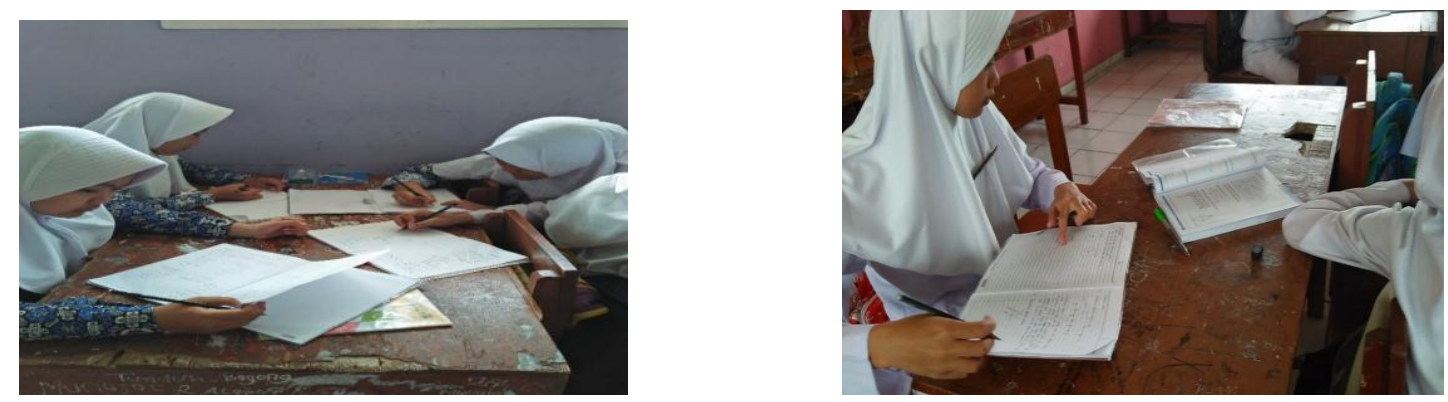

\section{Gambar 3. Siswa Membuat Mind Mapping}

Setelah tahap persiapan dengan menanya selanjutnya masuk ke tahap inisiasi dan akuisi dimana tahap ini masih tentang menanya dan mencoba, guru mengarahkan siswa untuk membangun koneksi antra materi pra-syarat (garis dan sudut) dengan materi yang akan dipelajari yaitu segitiga dan segiempat dengan memanfaatkan mind mapping dengan menanyakan kepada siswa apa yang siswa ketahui tentangsegitiga dan segiempat siapakah yang bersedia mendefinisikan segitiga dan segiempat melalui mind mapping yang mereka buat.

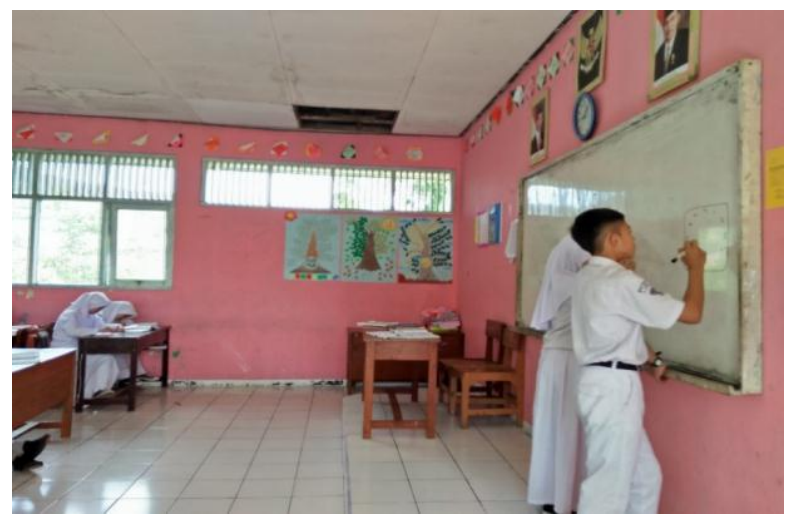

\section{Gambar 4. Membuat dan Mempresentasikan Mind Mapping}


Kemudian tahap selanjutnya dalam pembelajaran Brain Based Learning adalah elaborasi, pada tahap ini ada proses menalar dan mengkomunikasikan, guru mengarahkan siswa untuk memproses dan mempresentasikan koneksi materi segitiga dan segiempat yang terbentuk melalui bertukar pendapat dalam kelompok.

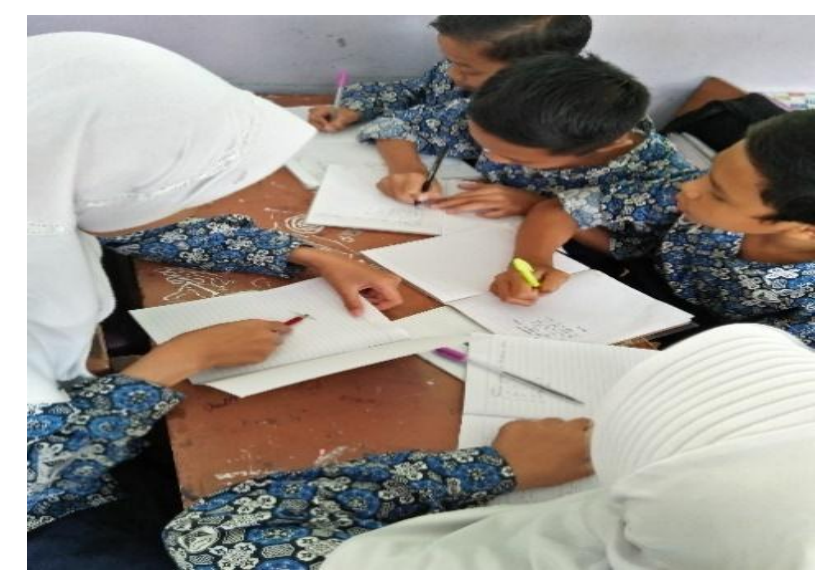

Gambar 5. Diskusi Antar kelompok

Setelah tahap elaborasi selesai dilanjutkan dengan tahap inkubasi dan memasukan memori secara bersamaan pada tahap ini terjadi proses mengkomukasikan, guru memberikan waktu istirahat dan waktu mengulang atau meninjau ulang materi yang sudah dipelajari dengan memutar musik atau memberikan game bersamaan dengan memberikan soal sederhana (LKS) berkaitan dengan segitiga dan segiempat untuk dikerjakan dan dipresentasikan secara santai.

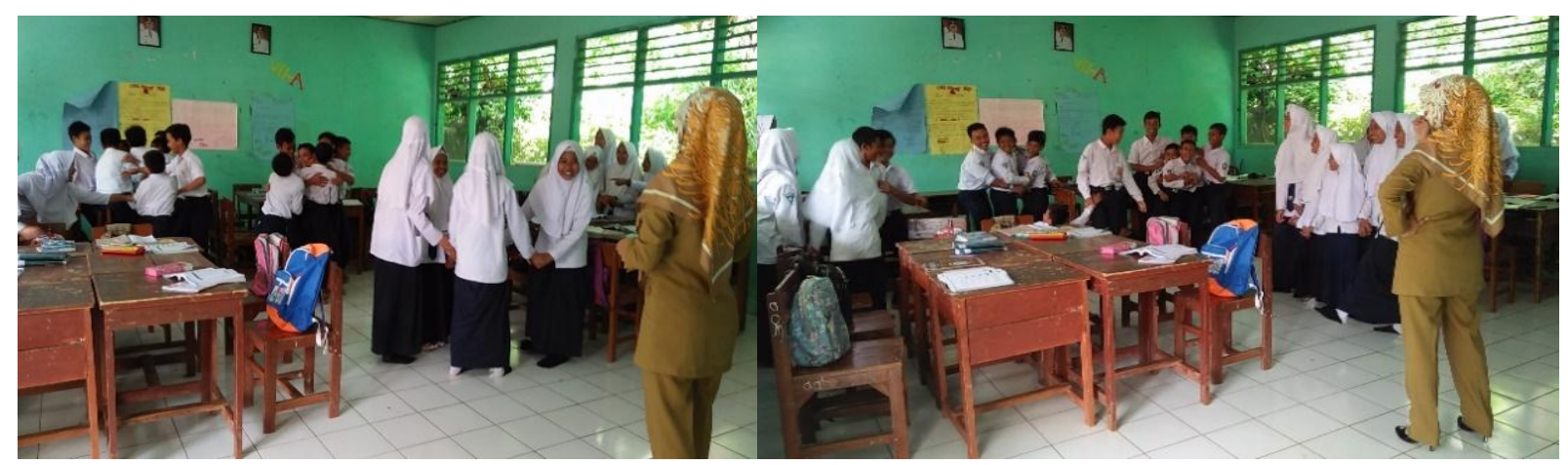

Gambar 6. Game Saat Pembelajaran 
Kemudian masuk ke tahap verifikasi dan pengecekan keyakinan dimana ditahap ini juga masih terjadi proses mengkomunikasikan, guru mengecek tingkat pemahaman siswa tentang materi segitiga dan segiempat yang telah dipelajari dengan meminta salah satu peserta didik untuk menyimpulkan pemahamannya tentang materi yang sudah dipelajari untuk kemudian guru memberi penguatan tentang apa yng disampaikan oleh siswa.

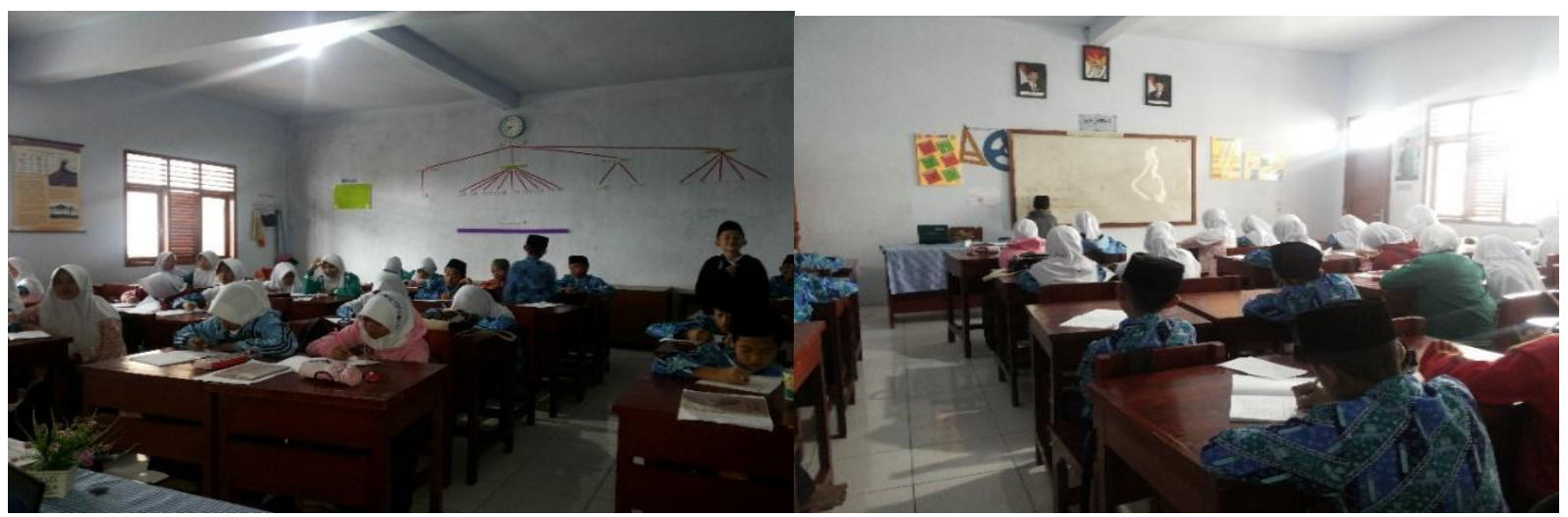

Gambar 7. Tahap Pengecekan Pemahaman

Tahap terakhir pada pendekatan ini adalah perayaan dan integritas dimana guru menanamkan pentingnya rasa cinta dari belajar dengan memberikan motivasi terkait materi yang dipelajari, pada kegiatan akhir pembelajaran siswa diberikan soal tes sebagai tolak ukur kemampuan siswa terhadap materi yang telah dipelajari. Selain daripada itu siswa di arahkan kaitan materi yang akan dipelajari pada pertemeuan berikutnya sehingga diharapkan siswa agar tetap belajar materi yang telah disampaikan.

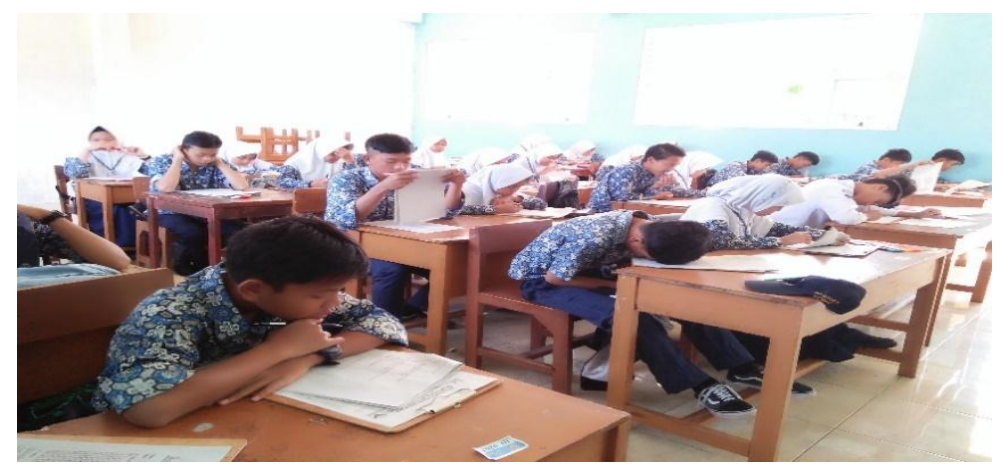

Gambar 8. Tahap Akhir 


\section{KESIMPULAN}

Berdasarkan analisis data dan pembahasan yang dikemukakan sebelumnya, diperoleh beberapa simpulan sebagai berikut:

1. Peningkatan kemampuan koneksi matematik siswa yang pembelajarannya menggunakan pendekatan Brain Based Learning lebih baik daripada yang pembelajarannya menggunakan pembelajaran biasa.

2. Self-efficacy matematik siswa yang pembelajarannya menggunakan pendekatan Brain Based Learning lebih baik daripada yang menggunakan pembelajaran biasa.

3. Terdapat asosiasi dengan kriteria sedang antara kemampuan koneksi matematik dan selfefficacy siswa yang pembelajarannya menggunakan pendekatan Brain Based Learning.

\section{REFERENSI}

Lestari, K. E. (2014). Implementasi Braind Based Learning untuk Meningkatkan Kemampuan Koneksi dan Berpikir Kritis Serta Motivasi Belajar Siswa SMP. Jurnal Pendidikan UNSIKA. Vol. 2 - No 1

Ruseffendi, E,T.(2010). Dasar Dasar Penelitian Pendidikan \& Bidang Non-Eksata Lainnya. Bandung: Tarsito.

Subaidi, A. (2016). Self-Efficacy Siswa dalam Pemecahan Masalah Matematika. Jurnal Pendidikan Universitas Madura. Vol 1- No 2

Yoenanto, N. H. (2010) . Self-regulated Learning dengan Selfefficacy pada Siswa Akselerasi Sekolah Menengah Pertama. INSAN Vol. 12 No. 02 